\title{
Effect of Silica Fume as a Waste Material for Sustainable Environment on the Stabilization and Dynamic Behavior of Dispersive Soil
}

\author{
Murat Türköz ${ }^{1, *(D)}$, Seyfettin Umut Umu ${ }^{2}$ (I) and Ogan Öztürk ${ }^{1}$ (1) \\ 1 Department of Civil Engineering, Eskisehir Osmangazi University, Eskisehir 26480, Turkey; \\ oganozturk@gmail.com \\ 2 Transportation Vocational School, Eskisehir Technical University, Eskisehir 26480, Turkey; \\ suumu@eskisehir.edu.tr \\ * Correspondence: mturkoz@ogu.edu.tr; Tel.: +90-222-2393750
}

Citation: Türköz, M.; Umu, S.U.; Öztürk, O. Effect of Silica Fume as a Waste Material for Sustainable Environment on the Stabilization and Dynamic Behavior of Dispersive Soil. Sustainability 2021, 13, 4321. https: //doi.org/10.3390/su13084321

Academic Editors: Andres Seco Meneses and Marc A. Rosen

Received: 22 February 2021

Accepted: 9 April 2021

Published: 13 April 2021

Publisher's Note: MDPI stays neutral with regard to jurisdictional claims in published maps and institutional affiliations.

Copyright: (c) 2021 by the authors. Licensee MDPI, Basel, Switzerland. This article is an open access article distributed under the terms and conditions of the Creative Commons Attribution (CC BY) license (https:// creativecommons.org/licenses/by/ $4.0 /)$.

\begin{abstract}
The use of dispersive soils, which are common in many parts of the world, in engineering applications such as water structures, earthen dams and road embankments is possible with their improvement. Recently, the effects of different chemicals on the stabilization of dispersive soils have been investigated. The use of waste materials in stabilization is preferred both because of the more sustainable environment and the economic advantages it provides. The use of silica fume (SF) as a waste material in different engineering applications provides an important advantage in environmentally and economically sustainable ways. Many studies have been carried out regarding silica fume, especially in the construction industry. Although SF is used in many industries, there is no study about its potential impact on the stabilization and dynamic properties of dispersive soils. In this study, first, Atterberg limits and standard Proctor compaction tests were performed on the mixtures prepared by adding different SF percentages $(0,5,10,15,20,25$ and 30\%). Afterward, pinhole tests and resonant column tests were performed to determine dispersibility and dynamic properties on the samples prepared by compaction characteristics for each SF percentage reached. In general, it was determined that SF contributed to a change in soil class, and improvement in dispersibility and dynamic properties of the soil sample, depending on SF content; positive effects of SF were observed in terms of shallow soil improvement.
\end{abstract}

Keywords: dispersive soil; silica fume; stabilization; dynamic properties

\section{Introduction}

Some soils that tend to dissipate spontaneously in water are suspicious in terms of erosion and piping. These soils are known in geotechnical engineering as dispersive clay or dispersive soil. Dispersive soils, which are not structurally stable, can be easily dispersed and eroded in the presence of water. When dispersive clay soils are used as building material in hydraulic structures, embankment dams and road embankments, they can cause serious problems and structural damage. Dispersive clays began to be defined in civil engineering practice in the early 1960s. As a result of the research on piping collapse in earth dams in Australia, it was revealed that it is caused by the presence of dispersive clays. In the following years, qualitative and quantitative experimental methods for the identification of dispersive clays were developed [1].

Although dispersive soils are thought to exist only in countries with arid or semiarid climates, many countries around the world have encountered problems caused by dispersive soil [2-7]. Thirty-seven percent of earthen dams worldwide have collapsed due to piping caused by dispersive erosion [8]. Dispersive soil-induced internal erosion also occurred in the Teton dam failure, which caused financial losses of around US\$ 400 million and more importantly, resulted in the death of 14 people [9]. Treatment of dispersive soils is 
usually done with chemical additives having different properties. This process eliminates the costs of transportation and material procurement that would occur when replacing problematic soil with quality material. Thus, natural resources are preserved and carbon dioxide consumption can be prevented for a sustainable environment during material supply and transportation.

Recently, the effects of different chemicals and substances on the stabilization of dispersive soils have been investigated. Bhuvaneshwari et al. [10] stated that 5\% lime additive is sufficient for the stabilization of dispersive soils; Umesha et al. [4] showed that $3 \%$ lime improved the dispersibility of the soil and additionally the unconfined compressive strength increased. Indraratna et al. [2] and Savas et al. [11] demonstrated that class C fly ash, which is rich in lime, can be used successfully in dispersive soil stabilization. Turkoz and Vural [12] found a significant improvement on the stabilization and strength of soils with different dispersive characteristics when mixed with natural zeolite in different proportions with 3\% cement. In the study conducted by Turkoz et al. [13], it was found that the soil, which exhibits both dispersive and expansive behavior, was improved with use of 5 to $7 \%$ magnesium chloride $\left(\mathrm{MgCl}_{2}\right)$ solution; strength parameters increased at $7 \%$ additive level, depending on the curing time. In another study by Joga et al. [14], xanthan gum, which is preferred as a biopolymer, was used for the stabilization of dispersive soils. In the study, both improvement in dispersion properties and increase in strength were found. As a result, it has been observed that these chemicals and substances significantly reduce the dispersion degree of the soil and at the same time create great increases in its strength.

The use of industrial wastes as an engineering material for the improvement of problematic soils can lead to less environmental pollution and also provides economic benefits. Silica fume is an abundant material, and it is about $40 \%$ cheaper than other materials such as Portland cement [15]. Total annual silica fume production in the world is around 1 million tons. Of this total, 130,000 tons are produced in the USA and 120,000 tons are produced in Norway. In North America, there are 13 plants where silicon, silica fume and ferrosilicon are produced [16]. The use of silica fume (SF) in different engineering applications provides an important advantage in environmentally and economically sustainable ways. SF has been used both as a partial cement replacement in concrete production [17-21] and to improve the engineering properties of problematic soils [22-24]. SF was first used in several countries during the industrial revolution of the mid-twentieth century to reduce the release of material into the atmosphere [25]. Since then, many studies and various applications have been carried out regarding silica fume, especially in the construction industry [26]. Previous studies reported that in a cubic yard of concrete, $10 \%$ by weight contains cement and around 0.9 tons of carbon footprint is generated per ton of cement. In the cement production process, the enormous consumption of fossil fuels results in an enormous carbon footprint. Therefore, the use of waste materials in concrete production instead of cement contributes to less natural resource consumption and a smaller carbon footprint [27].

Ay and Topçu [28] examined the properties of concretes prepared using silico ferrochrome fume containing $85.5 \% \mathrm{SiO}_{2}$. For this purpose, $\mathrm{SF}$ was added in dosage ratios of $0-5 \%$ by weight of cement and a series of test samples were prepared from these concrete mixes. From the test results, it was concluded that concrete containing SF with a low additive ratio of $2 \%$ and a water/cement ratio of 0.50 provided satisfactory strength. In addition, hardness, ultrasound velocity and unit weight were improved. It is also stated that it would be economical to use SF, which is industrial waste, in concrete. Tonak et al. [29] examined the cost effect of using SF in cement production. In their research, they stated that adding $10 \%$ SF to the cement mill during the grinding stage decreases the grinding time by $20-25 \%$, and thus, 20-25\% electrical energy savings can be achieved. It was stated that the production capacity of the mill increased by approximately $25 \%$ due to the shorter grinding time. Topçu and Kaval [30] also conducted a study on the economic analysis of the use of silica fume in concrete. Ferrosilicon SF obtained from Antalya Etibank Electrometallurgy 
Corporation in Turkey was used in the study. With the use of $10 \% \mathrm{SF}$, the strength of 300-, 350- and 400-dosed control concretes was obtained in 235-, 254- and 325-dosed concrete, and 17,23 and $14 \%$ of the cost of binder material was saved, respectively. It was determined that more economical concrete production could be made with the use of SF.

The higher specific surface area, cementation effect and pozzolanic activity of SF attributed higher potential to use as an alternative of cement and lime [31]. Cement has been used as a conventional chemical stabilizer to improve the engineering properties of soil, such as strength and durability; however, it causes global warming due to $\mathrm{CO}_{2}$ emission. Therefore, to reduce the carbon emission caused by cement required its substitute $[32,33]$. Liu et al. [34] conducted a study on the laboratory evaluation of environmentally friendly pervious concrete pavement material containing silica fume. In the study, different levels of silica fumes $(3,6,9$ and $12 \%)$ were used instead of cement by the equivalent volume method. The results showed that the addition of silica fumes significantly increased the strength and freeze-thaw resistance of pervious concrete. The positive effects of silica fume on cement concrete properties have been reported by many researchers $[35,36]$. Sezer [37] suggests a SF content of $5-10 \%$ to prevent the bleeding of concrete and increased protection against sulfate attacks and chloride ions. Based on the superior performance, silica fumes have been widely used in traditional cement concrete as a modifier.

In the literature, different studies were conducted to evaluate the effect of silica fume on problematic soils [38-42]. In these studies, the performance of swelling and dispersive soils treated with SF is evaluated in terms of the strength properties, mostly in the static state, together with the change in their geotechnical index properties. Abd El-Aziz et al. [38] found that the engineering properties of the soil were improved by adding lime $(\mathrm{L})$ in the range of 5-9\% combined with 10\% silica fume. Al-Zairjawi [39] examined the impact of a cement and silica fume additive on the compaction characteristics and strength of a high plasticity clayey soil. Test results showed that $8 \%$ cement $+6 \%$ silica fume decreased the maximum dry density from 1.64 to $1.55 \mathrm{~g} / \mathrm{cm}^{3}$ and increased the optimum water content from 19 to $23 \%$. In Bharadwaj and Trivedi [40], a series of laboratory experiments were conducted on samples with $0,5,10$ and $15 \%$ of silica fume by weight of dry soil. The test results showed a significant change in the consistency limits of samples containing silica fume. In addition, the differential free swell decreased from 48.46 to $9 \%$, showing an appreciable decrease in swelling behavior. It was shown that swelling potential decreased with an increase in percent silica fume treatment. Amina and Rani [41] used hydrated lime and silica fume as a waste material for treatment of the dispersive soil. They concluded that the addition of suitable additives such as lime and lime + silica fume caused a significant decrease in the dispersive characteristics of the soil. From the experiments, it was observed that $5 \% \mathrm{~L}$ and $2 \% \mathrm{~L}+12 \% \mathrm{SF}$ decreased the dispersive characteristics of the soil. AlSoudany [42] investigated the feasibility of stabilizing and improving the geotechnical properties of soft clay soil using different proportions of silica fume $(0,3,5$ and $7 \%$ ). Classification, specific gravity, compression properties and swelling pressure, California bearing ratio (CBR) and unconfined compressive strength (UCS) tests were carried out on modified soils. As a result, it was observed that the plasticity index and liquid limit decreased depending on the increasing silica fume content. The increase in silica fume resulted in an increase in optimum water content while the maximum dry unit weight values decreased. UCS, CBR and swelling pressure are improved using silica fume.

From the literature studies on the use of silica fume for soil stabilization, it is understood that generally the silica fume is used as an additive either alone or in combination with different additives such as lime and cement to improve the engineering properties of swelling soils $[43,44]$. Fattah et al. [43] found that the bearing capacity of a square foundation built on soft clay soil mixed with lime-silica fume was increased. Using different proportions of lime $(2,4$ and $6 \%)$ and silica fume $(2.5,5$ and $10 \%)$, the optimum silica fume percentage was determined and mixed with lime percentages. The slurry mixture was injected around the foundation at different depths and distances. An increase in the bearing capacity in the range of $6.58-88 \%$ was obtained with injection at a distance of $0.5 \mathrm{~B}$ 
(B: width of foundation) near the foundation. Goodarzi et al. [23] explored the potential use and effectiveness of expansive clay stabilization using a mixture of cement and silica fume (CSF). Cement and CSF blend with $10 \%$ cement replacement were separately added to a clay sample, and then a series of macro and micro level tests were performed under various curing regimes to evaluate the responses to the changes. In the sample with CSF, a greater strength (about 35\%) and a lower compression index (up to about $50 \%$ ) were obtained compared to single cement. Partial replacement of cement with SF was found to reduce both the binder dosage and curing time for successful treatment of the expansive clay, with a fact that SF contributes to waste recycling. Kalkan [44] determined that silica fume admixture effectively reduced desiccation cracks of expansive clays. In the other study conducted by Kalkan [45], the effect of wetting-drying cycles on the swelling behavior of a clay soil modified with different percentages of silica fume $(10,20,25$ and $30 \%)$ was investigated. The positive effect on the swell percentage and swell pressure of modified soil was observed in the samples prepared at 25 to $30 \%$ silica fume additive level. Tiwari and Satyam [46] conducted an experimental study to evaluate the effect of polypropylene fiber on the swelling pressure and expansion properties of silica fume stabilized clay soil. The study was carried out in three stages and finally the effect of combinations of different fiber proportions $(0.25,0.50$ and $1.00 \%)$ and silica fume $(2,4$ and $8 \%)$ was evaluated together. The soil expansive behavior was improved, and the soil class changed from high plasticity clay $(\mathrm{CH})$ to low plasticity clay $(\mathrm{CL})$ due to the decrease in the plasticity index and liquid limit values. As a result of the research, it was stated that silica fume is a valuable material to modify expansive clay property due to silica reaction with the calcium and the calcium silicate hydrate (C-S-H) gel produced.

Silica fume, which is produced as a byproduct in the production of silicon and ferrosilicon alloys in the electrometallurgy industry, is a substance with high pozzolanic value due to its high content of amorphous silica. Although SF is used in many industries, there is no study concerning its potential impact on the stabilization and dynamic properties of dispersive soils. The dynamic properties of dispersive clay soils subjected to cyclic excitation are important in terms of design and should be evaluated by considering the soil dynamic properties, such as initial shear modulus $\left(\mathrm{G}_{0}\right)$, shear modulus $(\mathrm{G})$, modulus reduction curve $\left(G / G_{0}\right)$ and damping ratio (D) with respect to variation of shear strain amplitude. To summarize, it is seen that the effect of silica fume on the geomechanical properties of the swelling soils is evaluated in the previous studies; however, the improvement effects on dispersive soils are not fully known. In addition, there has been no study on the dynamic properties of dispersive soils treated with silica fume under cyclic excitation.

It is obvious that the performance of the silica fume additive used for shallow stabilization in engineering applications should also be addressed in dispersible soils. Lack of experimental studies on the dynamic behavior of dispersive soils stabilized with silica fume motivated this study.

\section{Materials and Methods}

The soil sample used in the experiments was excavated from a depth close to the surface and identification and classification tests were performed to determine the priority geotechnical properties of the soil sample based on the ASTM standards [47-51]. The geotechnical properties of the soil are presented in Table 1. From the grain distribution curve given in Figure 1, the soil sample contains $0 \%$ gravel, $23 \%$ sand, $46 \%$ silt and $31 \%$ clay. The soil sample having $51 \%$ liquid limit and $24 \%$ plasticity index values was classified as high plasticity clay $(\mathrm{CH})$ according to the Unified Soil Classification System [49]. From the chemical analysis results on the soil sample, exchangeable sodium percentage $(\mathrm{ESP}=30.2 \%)$, sodium adsorption ratio $(\mathrm{SAR}=22.7 \%)$, sodium $(\mathrm{Na}=79.5 \%)$ and total dissolved salt (TDS $=112.9 \%$ ), which are the primary indicators of dispersive soil behavior, were determined. 
Table 1. Geotechnical properties of the soil sample.

\begin{tabular}{cc}
\hline Parameter & Value \\
\hline Grain Size & \\
Gravel (\%) & - \\
Sand (\%) & 23 \\
Silt (\%) & 46 \\
Clay (\%) & 31 \\
Atterberg Limits & \\
Liquid Limit, LL (\%) & 51 \\
Plastic Limit, PL (\%) & 27 \\
Plasticity Index, PI (\%) & 24 \\
Specific Gravity, Gs & 2.65 \\
Classification (USCS) & $\mathrm{CH}$ \\
Activity, A & 0.77 \\
Maximum Dry Density (Mg/m ${ }^{3}$ ) & 1.584 \\
Optimum Water Content (\%) & 20.5 \\
\hline
\end{tabular}

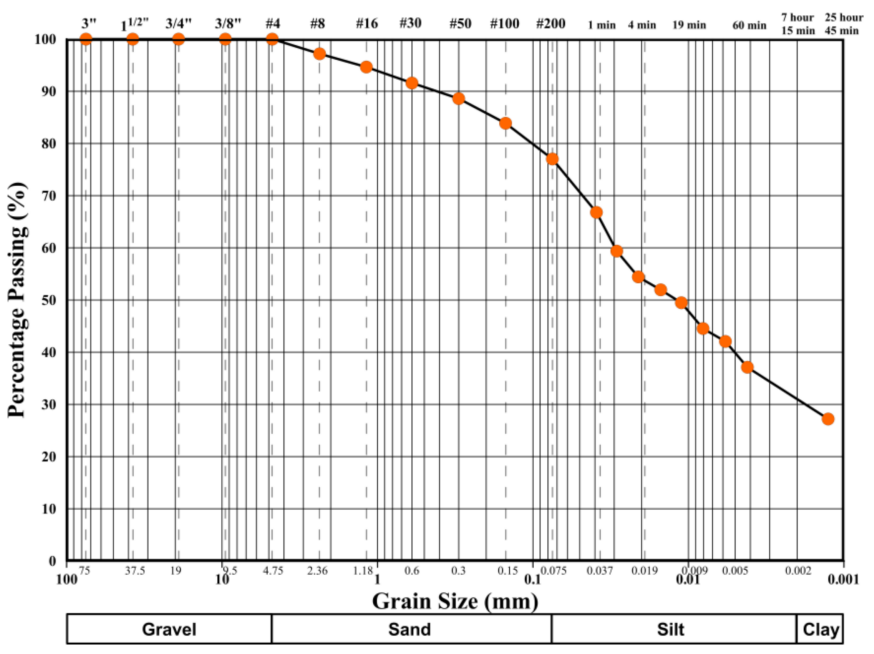

Figure 1. Particle size distribution of the soil sample used in the study.

As a result of the X-ray analysis performed on the soil sample to determine the mineral types, it was determined that the clay is mainly composed of illite, and smectite and kaolinite as accessories (Figure 2).

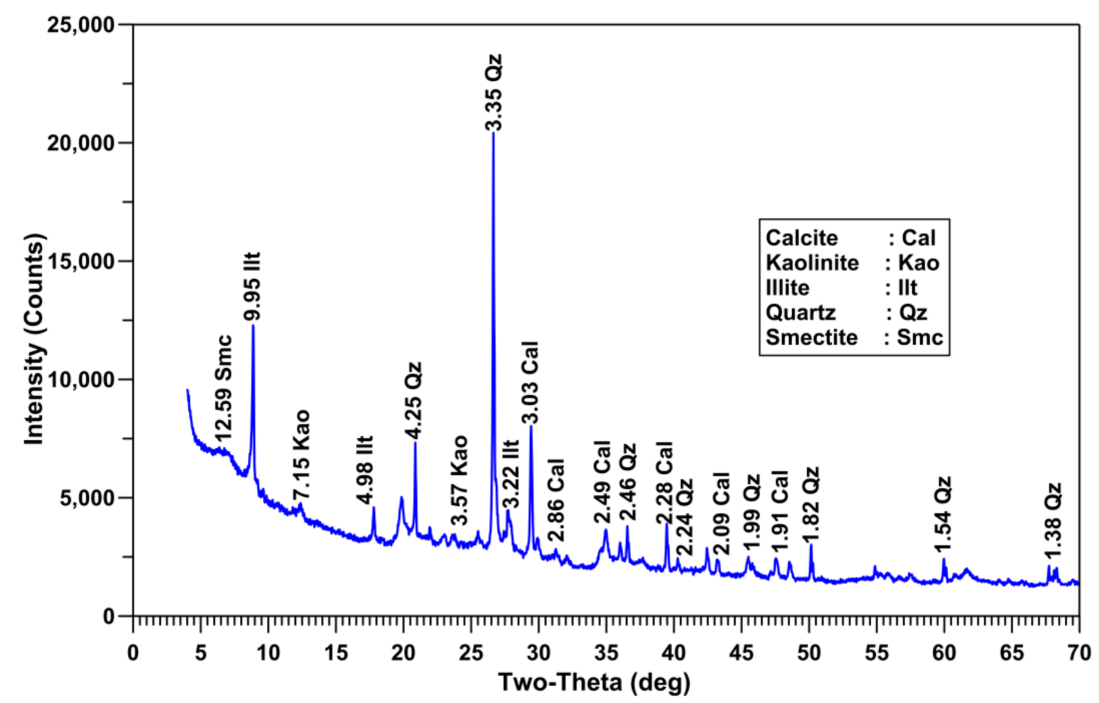

Figure 2. X-ray diffraction pattern of the soil sample. 
The chemical compositions of the soil and silica fume additive are presented in Table 2. From Table 2, it is seen that the soil sample contains a high amount of $\mathrm{SiO}_{2}$ and low amount of $\mathrm{Al}_{2} \mathrm{O}_{3}$, and this situation can be evaluated as an indicator that the soil has a dispersive characteristic, as stated by Bell and Walker [52].

Table 2. Chemical composition of the soil and silica fume additive.

\begin{tabular}{ccc}
\hline Property & Silica Fume (\%) & Soil (\%) \\
\hline $\mathrm{SiO}_{2}$ & 66.92 & 52.27 \\
$\mathrm{MgO}$ & 9.52 & 1.68 \\
$\mathrm{~K}_{2} \mathrm{O}$ & 4.66 & 3.42 \\
$\mathrm{Na}_{2} \mathrm{O}$ & 4.52 & 1.61 \\
$\mathrm{Cr}_{2} \mathrm{O}_{3}$ & 3.48 & - \\
$\mathrm{Fe}_{2} \mathrm{O}_{3}$ & 1.27 & 6.47 \\
$\mathrm{Al}_{2} \mathrm{O}_{3}$ & 1.22 & 16.58 \\
$\mathrm{ZnO}$ & 1.08 & - \\
$\mathrm{CaO}$ & 0.98 & 5.13 \\
$\mathrm{Cl}$ & 0.70 & 0.10 \\
$\mathrm{SO}$ & 0.43 & 0.13 \\
$\mathrm{MnO}_{3}$ & 0.14 & 0.15 \\
$\mathrm{PbO}$ & 0.11 & - \\
$\mathrm{Ga}_{2} \mathrm{O}_{3}$ & 0.09 & - \\
$\mathrm{P}_{2} \mathrm{O}_{5}$ & 0.07 & 0.11 \\
$\mathrm{TiO}_{2}$ & 0.04 & 0.69 \\
Loss on ignition & 4.77 & 11.76 \\
\hline
\end{tabular}

Silica fume (SF) used in this study was obtained from Antalya Electrometallurgy Corporation in Turkey. The specific gravity of SF used in the study is 2.32. Chemical analyses presented within the scope of the study were performed at Eskişehir Osmangazi University Central Research Laboratory. The chemical properties of silica fume are shown in Table 2. Silica fume, which has an annual production of approximately one million tons in the world, is a byproduct in the manufacture of silicon and ferrosilicon alloys, and is many times thinner than fly ash. Silica fume, which was previously discharged from the chimneys of factories and caused air pollution, has low unit weight, low compressibility and high specific surface area, but also has high pozzolanic activity due to its high silica content $[8,53]$. The individual silica fume particles are extremely small: about $1 / 100$ the size of an average cement particle, with most particles (>95\%) smaller than $1 \mu \mathrm{m}$ [25].

\subsection{Specimen Preparation for the Tests}

The soil sample obtained by excavating from the field was laid in an open area in the laboratory and left to dry for a long time. To ensure a homogeneous distribution, the lump soil sample was first pulverized with a plastic mallet, then passed through a No. 4 sieve on a flat area and filled into bags after blending well. The air-dried soil sample was mixed with silica fume added $(0,5,10,15,20,25$ and 30\%) as percentage of dry weight of the soil. All mixing was performed manually, and special attention was paid to obtaining a homogeneous mixture in each step. Compaction characteristics of the soil samples mixed with different silica fume (SF) additive percentages were determined by Standard Proctor test.

The specimens used in both pinhole and resonant column experiments were prepared with the compaction characteristics found in each SF additive series. The specimen, which were compacted in molds specific to each experiment, were removed from the molds and after being wrapped in stretch film, they were kept in desiccators at approximately $25^{\circ} \mathrm{C}$ in the laboratory for one day. Resonant column experiments were performed under a wide shear strain amplitude range $\left(10^{-3}-10^{-1} \%\right)$.

Although the silica fume used in previous studies contains $90 \%$ or more amorphous silica, from the chemical analysis results presented in Table 2 it is seen that the silica fume 
used in this study contains $66.92 \% \mathrm{SiO}_{2}$. On this basis, in this study, the silica fume additive percentage used for soil improvement was increased up to $30 \%$. In all experiments, distilled water, free from mineral residues and chemical elements recommended by USBR 5410 [54], was used to evaluate the dispersive characteristic of clay soil in the laboratory environment.

\subsection{Experimental Study}

\subsubsection{Atterberg Limits}

When clay minerals are present in fine-grained soil, that soil can be remolded in the presence of some moisture without crumbling. This cohesive nature is due to adsorbed water surrounding the clay particles. The engineering behavior of fine-grained soils varies greatly depending on the water content they contain. Changes in the consistency of soils depending on the water content are defined by the limit water content values such as liquid limit (LL) and plastic limit (PL). These limits are also known as Atterberg limits. Atterberg limit experiments were performed on air-dried soil fraction passing a $425 \mu \mathrm{m}$ sieve. LL and PL tests were carried out by following the procedure in ASTM [48] on the mixtures prepared by mixing the soil sample using different silica fume additive ratios $(0,5,10,15$, $20,25$ and $30 \%)$.

\subsubsection{Compaction Test}

In the construction of highways, railways, earth dams and many other engineering structures, the soils brought to the fill area in loose condition are compacted under different compression energies to increase the dry densities. The laboratory test commonly used to obtain maximum dry density and optimum water content is called the Proctor compression test. Standard Proctor compaction tests [51] were performed at each level of silica fume additive, and the optimum water content and maximum dry density values required for the preparation of the specimens were determined.

\subsubsection{Pinhole Test}

Dispersive soils cannot be determined from classical identification tests such as consistency limits and soil grain distribution. Special test methods have been developed to identify these soils. The pinhole test is an experiment developed to directly measure the dispersibility property of fine-grained compacted soils. In the test, a $1.0 \mathrm{~mm}$ diameter hole is drilled into a cylindrical soil sample of $25 \mathrm{~mm}$ length and $35 \mathrm{~mm}$ diameter prepared in the compaction characteristics determined in the standard Proctor compaction test. Distilled water is passed through this hole under 50,180 and $380 \mathrm{~mm}$ heads and at different hydraulic inclinations $(2,7$ and 15). The flow rate and the degree of turbidity of the water are recorded. As shown in Table 3, the USBR 5410 procedure was taken into account in evaluating the experimental results and determining the dispersibility classes [54].

Table 3. Pinhole test method and evaluation criteria for dispersive classification [54].

\begin{tabular}{|c|c|c|c|c|c|}
\hline $\begin{array}{l}\text { Head } \\
(\mathrm{mm})\end{array}$ & $\begin{array}{c}\text { Total Time } \\
\text { Interval } \\
\text { (min) }\end{array}$ & $\begin{array}{c}\text { Flow Rate } \\
(\mathrm{mL} / \mathrm{s})\end{array}$ & Effluence Appearance & Action Required & Classification \\
\hline 50 & 5 & $<1.0$ & Dark to clear & Continue at $50 \mathrm{~mm}$ head & - \\
\hline 50 & 5 & $1.0-1.4$ & Dark to cloudy & Terminate & D1 (Dispersive) \\
\hline 50 & 10 & $0.2-0.8$ & Clear to slightly cloudy & Raise head to $180 \mathrm{~mm}$ & - \\
\hline 50 & 10 & $0.8-1.4$ & Dark to slightly cloudy & Terminate & $\begin{array}{c}\text { D2(1.0-1.4) (Dispersive) } \\
\text { ND4 (0.8-1.0) (Intermediate) }\end{array}$ \\
\hline 180 & 5 & $0.6-1.2$ & Clear to slightly cloudy & Raise head to $180 \mathrm{~mm}$ & - \\
\hline 180 & 5 & $1.2-2.8$ & Clear to slightly cloudy & Terminate & $\begin{array}{l}\text { ND3 (1.2-2.0) (Intermediate) } \\
\text { ND4 (2.0-2.8) (Intermediate) }\end{array}$ \\
\hline 380 & 5 & $0.8-2.4$ & Clear to slightly cloudy & Terminate & $\begin{array}{l}\text { ND1 (0.8-1.6) (Non-dispersive) } \\
\text { ND2 (1.6-2.4) (Non-dispersive) }\end{array}$ \\
\hline 380 & 5 & $2.4-3.2$ & Dark to cloudy & Terminate & ND3(Intermediate) \\
\hline
\end{tabular}




\subsubsection{Resonant Column Test}

Initial shear modulus, $G_{0}$, is a significant parameter in defining linear and nonlinear elastic soil behavior and is calculated from shear wave velocity in the field or laboratory $[55,56]$. The laboratory test used to determine the initial shear modulus is the resonant column test apparatus ( $\mathrm{RC})$, which is based on the theory of wave propagation in prismatic bars [57]. Dynamic properties of soils such as damping ratio and initial shear modulus can be determined using RC test apparatus between $\gamma(\%)=10^{-4}-10^{-1}$ shear strain amplitude.

The RC test device used in the experiments (Figure 3) is a test apparatus with one side fixed and the other free. The soil sample is fixed at the bottom and free at the top where the harmonic load is applied. During the test, the soil sample is consolidated and then subjected to dynamic torsional excitation that is controlled and supplied by an AC servo motor at the top of the apparatus. The shear wave velocity was obtained by measuring the first-mode resonant frequency. The maximum shear modulus was calculated from this shear wave velocity and the soil density. Material damping obtained from the freevibration decay after the forced vibration was stopped. After the determination of the maximum shear modulus and the minimum damping ratio, the cyclic torsional harmonic load amplitude was increased to obtain the strain-dependent shear modulus and damping values for a wide strain range [58].

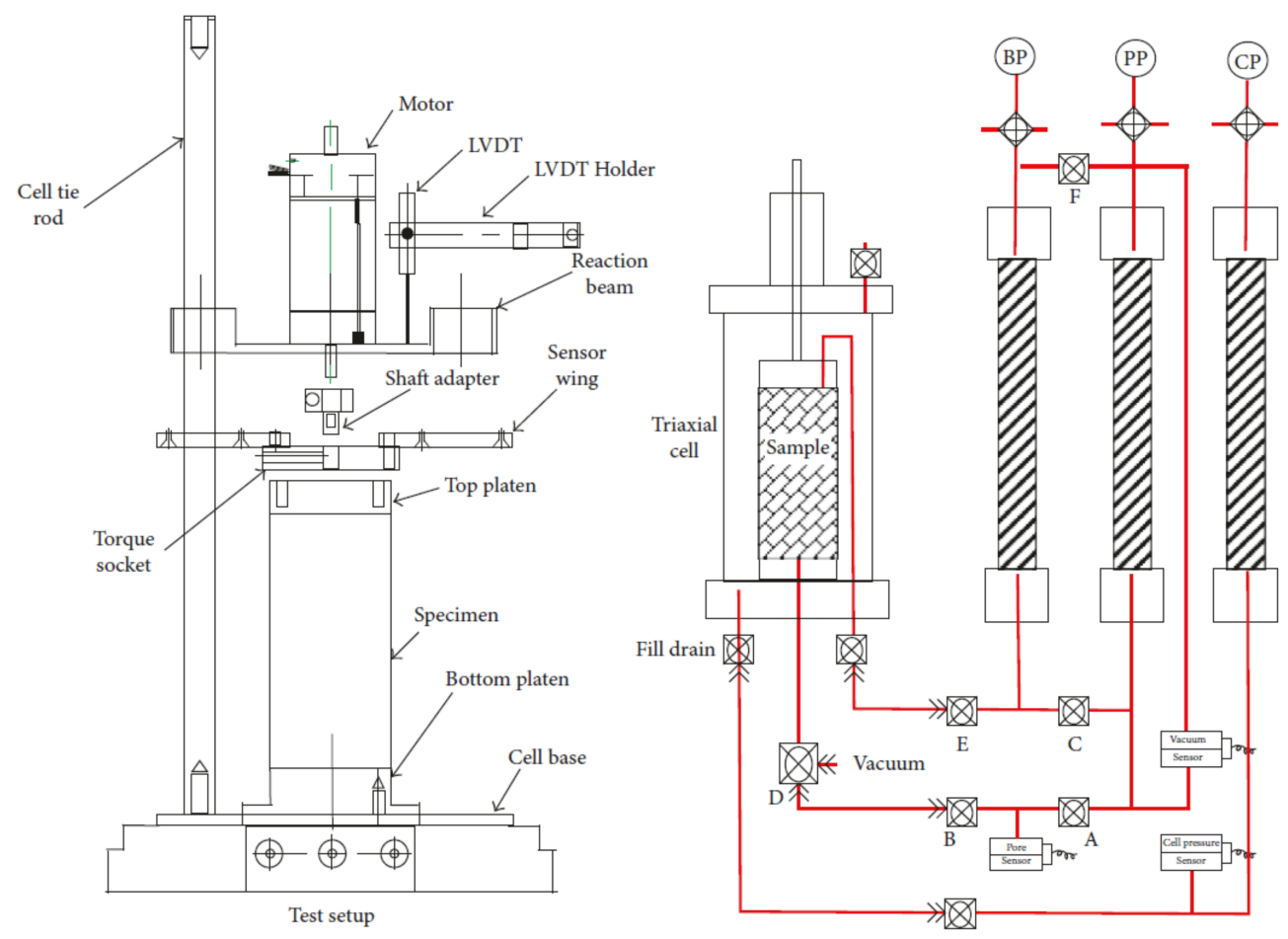

Figure 3. Schematic cross-section of resonant column apparatus and pressure panel used in experiments.

In this test, the samples were prepared by statically compacting soil into a $50 \mathrm{~mm}$ diameter and $130 \mathrm{~mm}$ height stainless steel tube with the compaction properties found in each SF additive contents. The prepared samples were wrapped in cling film, put in a desiccator and exposed to cure for one day in the laboratory environment. Resonant column experiments were performed at low effective cell pressures $(20,40$ and $60 \mathrm{kPa})$ because stabilization occurred at shallow depths in field applications. 


\section{Results and Discussion}

This section may be divided by subheadings. It should provide a concise and precise description of the experimental results, their interpretation, as well as the experimental conclusions that can be drawn.

\subsection{Effect of Silica Fume on Atterberg Limits}

The effect of the silica fume additive on the change in the liquid limit (LL), plastic limit (PL) and plasticity index (PI) values of the soil sample, depending on the silica fume content, is presented in Table 4 . Although the liquid limit gradually decreased with increasing silica fume content, the change in the plastic limit was very limited. As a result of this situation, the plasticity index, which is the difference between the liquid limit and the plastic limit, decreased due to the increasing silica fume content. At 5, 10, 15, 20, 25 and $30 \%$ silica fume content, the LL value decreased by 10,12, 16, 24, 25 and $29 \%$, respectively. Similarly, at the same SF contents, there was a $16.7,21,29.17,50,54.17$ and $62.5 \%$ reduction in PI values, respectively. The reduction in plasticity properties of the soil sample can be attributed to the replacement of highly plastic clay particles with nonexpansive silica fume particles. Besides, the addition of silica fume to clay soils causes flocculation, thus reducing liquid limit and plasticity index. Similar situations were observed in the study by Al-Soudany [42], Kalkan [45] and Phanikumar et al. [59]. As seen in Figure 4, the soil class changed from $\mathrm{CH}$ (high plasticity clay) soil class to ML (low plasticity silt) soil class with silica fume content above $15 \%$.

Table 4. The effect of silica fume additive on Atterberg limits.

\begin{tabular}{cccc}
\hline \multirow{2}{*}{ Silica Fume, SF (\%) } & \multicolumn{3}{c}{ Atterberg Limits } \\
\cline { 2 - 4 } & LL (\%) & PL (\%) & PI (\%) \\
\hline 0 & 51 & 27 & 24 \\
5 & 46 & 26 & 20 \\
10 & 45 & 26 & 19 \\
\hline 15 & 43 & 26 & 17 \\
20 & 39 & 27 & 12 \\
25 & 38 & 27 & 9 \\
30 & 36 & 27 &
\end{tabular}

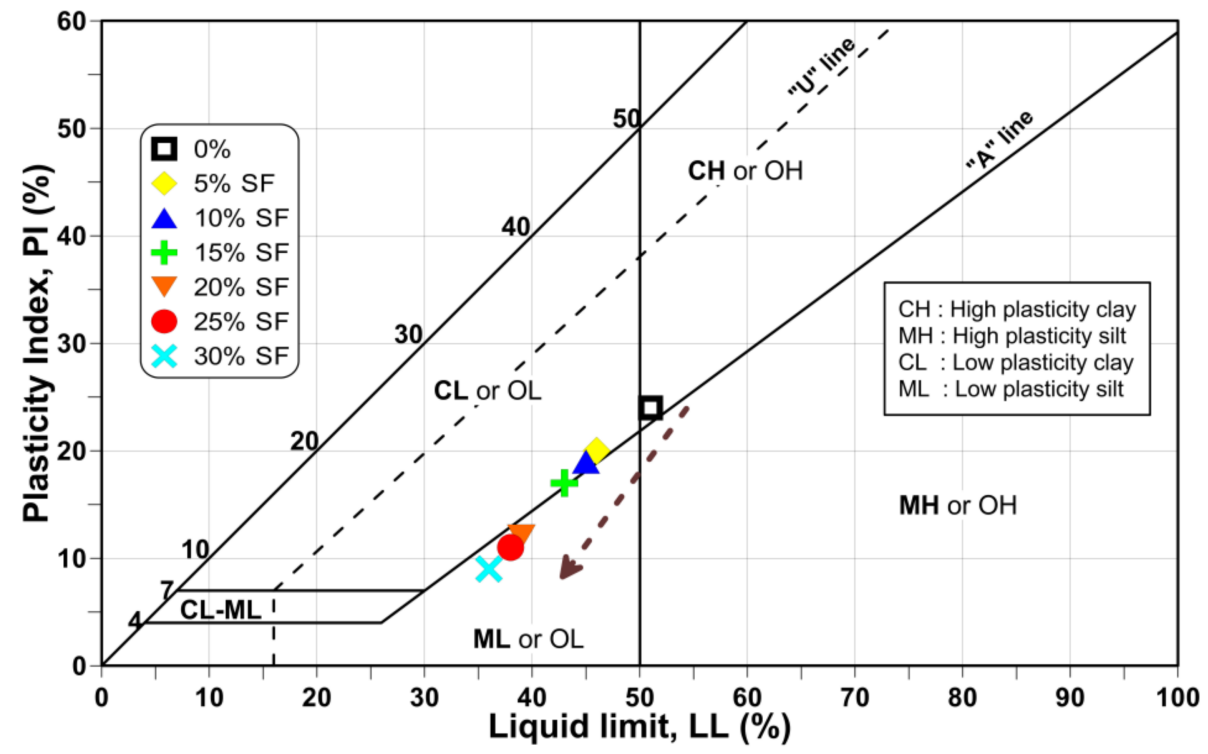

Figure 4. Locations of soil and soil-silica fume mixtures on the plasticity chart. 


\subsection{Effect of Silica Fume on Compaction Test Results}

The compaction curves obtained from the standard Proctor test on different percentages of silica fume-soil mixtures are presented in Figure 5. The optimum water content and maximum dry density values determined from the compaction curves are also given in Table 5. As seen from Figure 5, compaction curves up to 15\% silica fume additive level show a wider curve formation, while silica fume contents greater than $15 \%$ offer narrower curve formation. In other words, greater than $15 \%$ silica fume stabilization tightens the compaction curve, resulting in dry density values in narrower water content ranges. When assessed in terms of compaction characteristics shown in Table 5, a remarkable decrease in maximum dry density was observed at $15 \%$ silica fume content. The maximum dry density value, which was $1.584 \mathrm{Mg} / \mathrm{m}^{3}$ without additives, reduced to $1.559 \mathrm{Mg} / \mathrm{m}^{3}$ at $15 \%$ additive content. There were no significant changes in maximum dry density (MDD) values with increasing SF contents. The increase in optimum water content (OWC) was relatively limited. This was due to the lower specific gravity of the silica fume compared to the soil, and therefore the additional void volume developed due to the low specific gravity (Gs) and particle sizes of the specimens with additives. As a result of the replacement of sodium cations in the dispersive soil with the silicon cations in the silica fume, the double layer thickness decreased and eventually this situation caused the flocculation of the grains. Similar results were obtained by Al-Azzawi et al. [60].

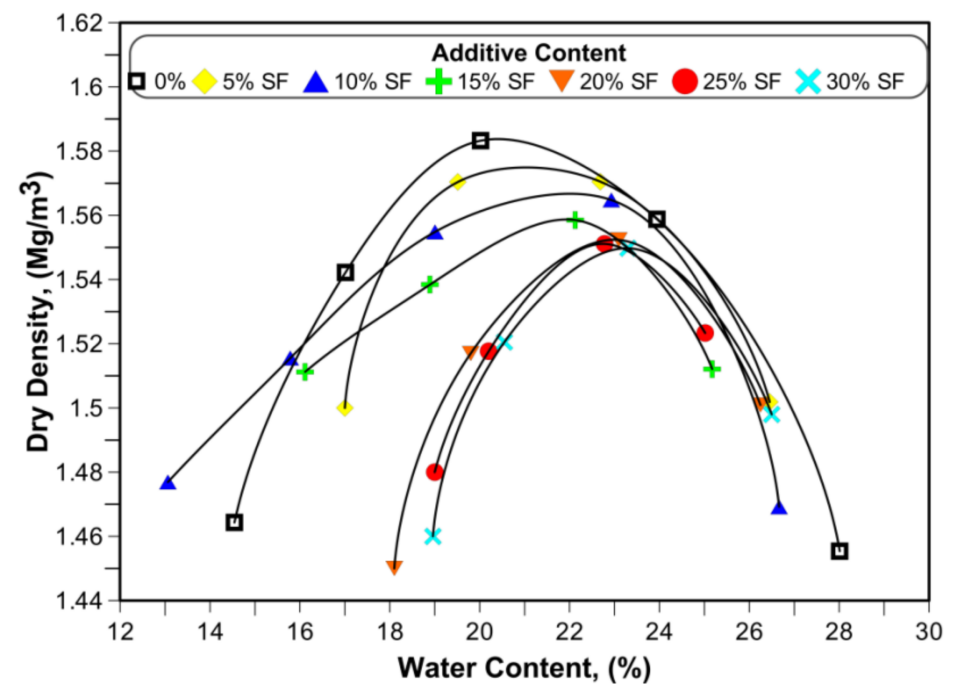

Figure 5. Compaction curves obtained from different additive content of silica fume-soil mixtures.

Table 5. Effect of silica fume additive on optimum water content and maximum dry density.

\begin{tabular}{|c|c|c|c|}
\hline $\begin{array}{c}\text { Silica } \\
\text { Fume } \\
(\%)\end{array}$ & Optimum Water Content $w_{\text {opt }},(\%)$ & $\begin{array}{l}\text { Maximum Dry Density } \\
\text { qdmaks }_{\text {d }}\left(\mathrm{Mg} / \mathrm{m}^{3}\right)\end{array}$ & $\begin{array}{c}\text { Specific } \\
\text { Gravity } \\
\mathrm{G}_{\mathrm{s}}\end{array}$ \\
\hline 0 & 20.5 & 1.584 & 2.65 \\
\hline 5 & 20.9 & 1.579 & 2.64 \\
\hline 10 & 21.9 & 1.571 & 2.64 \\
\hline 15 & 21.9 & 1.559 & 2.63 \\
\hline 20 & 22.8 & 1.553 & 2.63 \\
\hline 25 & 22.8 & 1.551 & 2.62 \\
\hline 30 & 22.9 & 1.550 & 2.62 \\
\hline
\end{tabular}

\subsection{Effect of Silica Fume on Pinhole Test Results}

The pinhole test results to evaluate the effect of silica fume on the dispersive behavior of the soil sample are presented in Figure 6 on the basis of the flow rate-time relationships. Table 6 also shows the effect of additive rate on dispersibility class collectively. From 
the chemical analysis results on the soil sample, it was determined that the exchangeable sodium percentage, which is an important indicator of dispersive behavior, was $30.2 \%$. Elges [61] and Knodel [62] assessed the exchangeable sodium percentage (ESP) value greater than 10 as an indication of the dispersive soil characteristic of the soil sample. As a result of the pinhole test, it was determined that the soil sample had highly dispersive properties and the dispersibility class was classified as D1. As seen in pinhole test method and evaluation criteria for dispersive classification presented in Table 3, the dispersibility classes of the soil are determined when the flow rates fall to a certain range. According to this evaluation card, if the flow rate is between certain values, it causes the dispersibility class to be the same. For example, while the flow rate of $0 \% \mathrm{SD}$ additive is close to $1.4 \mathrm{~mL} / \mathrm{s}$, it is around $1 \mathrm{~mL} / \mathrm{s}$ at $5 \% \mathrm{SD}$ additive rate (Figure 6). However, in both cases, the soil dispersibility class is classified as "D1" dispersive. A similar situation is valid for the 10 , 15 and $20 \%$ SD additive levels. The flow rate to all three additive levels is between 2 and $2.8 \mathrm{~mL} / \mathrm{s}$, and it is classified as "ND4" intermediate soil. For these three SD additive levels, the difference in flow rates may be due to the hole geometry initially drilled.

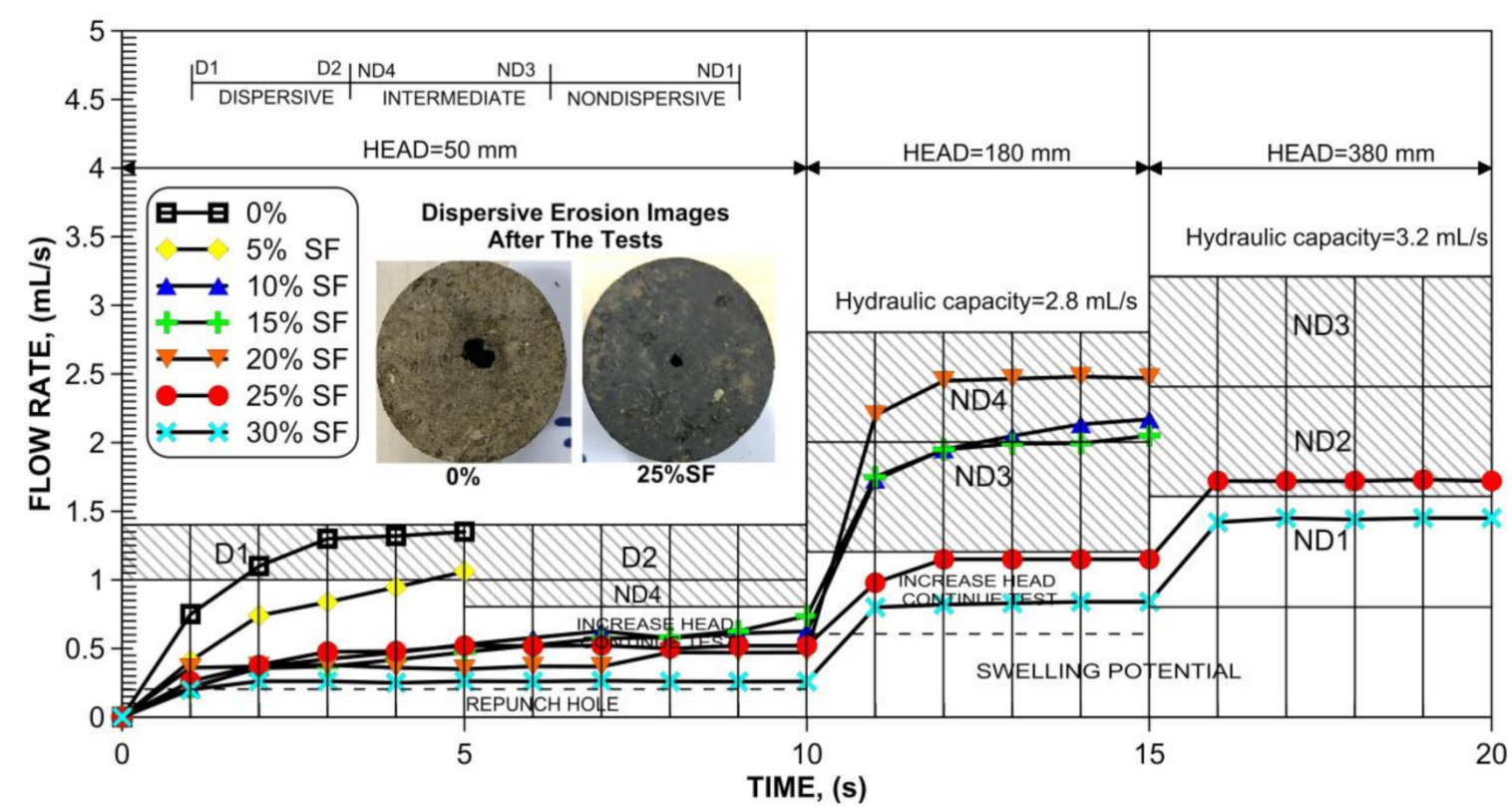

Figure 6. Pinhole test results of soil samples mixed with different silica fume additive contents.

Dispersive clays will rapidly erode as water flows through the $1 \mathrm{~mm}$ hole under a small water head pressure. Rapid enlargement of the hole is reflected in an increasing flow rate and the turbidity of the collected water. From the image presented in Figure 6, it can be seen how much the hole diameter increased by means of dispersive erosion. With the increasing amount of silica fume additive, an improvement in dispersibility was determined. Significant effect was achieved at $25 \%$ additive content and the dispersibility class was classified as ND2 (nondispersive). At the same time, the fact that the measured flow rate for nondispersive soils remains constant for each load stage is an indication that the pinhole diameter did not change during the experiment. Dispersive erosion depends on the clay content of the soil and the chemical properties of the clay, and the chemical properties of the water [63].

One of the important factors causing dispersion is the ratio of sodium cations absorbed on clay particle surfaces to multivalent cations (calcium and magnesium). The sodium cation, which has a higher hydration diameter, causes an increase in diffuse double layer thickness compared to other cations. This situation results in dispersion due to colloidal grains repelling each other. On the other hand, the presence of higher valence cations in the environment (e.g., $\mathrm{Ca}^{2+}, \mathrm{Mg}^{2+}$ and $\mathrm{Si}^{3+}$ ) contributes to the reduction of diffuse double layer (DDL) thickness and repulsive forces. As a result of this situation, unlike dispersion, 
colloids approach each other and create a flocculated structure. This phenomenon, which is part of the short-term reactions between the soil and the stabilizer, can lead to the formation of the flocculated structure [64].

Changes in soil properties during chemical treatment are probably due to the decrease in the thickness of the DDL resulting from the cation exchange between $\mathrm{Na}$ and $\mathrm{Ca}, \mathrm{Si}$ and $\mathrm{Al}$, and consequently the decrease in the repulsive forces of the clay particles $[62,65]$. In addition, the fact that the soil sample mainly contained illite and a small amount of smectite minerals contributed to the acceleration of the pozzolanic reaction. The soil structure may have changed from dispersive to flocculated structure due to the replacement of trivalent cations such as $\mathrm{Si}$ in the silica fume with the monovalent sodium cation $\left(\mathrm{Na}^{+}\right)$present in the soil sample. As a result of the chemical analysis, it was determined that the soil sample had a very high sodium adsorption rate $(\mathrm{SAR}=22.7 \%)$ and sodium percentage $(\mathrm{Na}=79.5 \%)$. The final improvement at $25 \% \mathrm{SF}$ content was due to the high amount of silica fume required to balance the high amount of sodium cation contained in the soil sample.

Table 6. Effect of soil-silica fume mixtures on dispersibility classes.

\begin{tabular}{cccccccc}
\hline \multirow{2}{*}{ Test } & \multicolumn{7}{c}{ Silica Fume Content (\%) } \\
\cline { 2 - 8 } & $\mathbf{0}$ & $\mathbf{5}$ & $\mathbf{1 0}$ & $\mathbf{1 5}$ & $\mathbf{2 0}$ & $\mathbf{2 5}$ & $\mathbf{3 0}$ \\
\hline Pinhole test class & D1 & D1 & ND4 & ND4 & ND4 & ND2 & ND1 \\
\hline D1 and D2, dispersive; ND3 and ND4, intermediate; ND1 and ND2, nondispersive.
\end{tabular}

\subsection{Resonant Column Test Results}

Shear modulus test results of mixed samples with different silica fume ratios obtained by the resonant column test are given in Table 7 . When the results presented in Table 7 are evaluated in general, it was found that initial shear modulus increased in all series with the increase of effective cell pressure. This is because the effective cell pressure, which compresses the spaces between the soil particles, increases and then the density of the sample increases. The initial shear modulus $\left(\mathrm{G}_{0}\right)$ values calculated from samples with $15 \%$ $\mathrm{SF}$ were the highest values compared to the initial shear modulus value of the samples $(0 \% \mathrm{SF})$ at $\gamma=0.001 \%$ shear strain amplitude and $\sigma_{0}^{\prime}=40-60 \mathrm{kPa}$ effective cell pressure (Figure 7d, Table 7). In addition, at $\sigma_{0}^{\prime}=20 \mathrm{kPa}$ effective cell pressure and $\gamma=0.001 \%$ shear strain amplitude, the initial shear modulus obtained in the mixed samples with $30 \% \mathrm{SF}$ was the highest value (Figure $7 \mathrm{~g}$ and Table 7).

The value of secant shear modulus ratio $G / G_{0}$ computed and the expression for the secant modulus in the cyclic loading is obtained from the Equation (1) [66]:

$$
\frac{\mathrm{G}}{\mathrm{G}_{0}}=\frac{1}{1+\gamma_{\mathrm{a}} / \gamma_{\mathrm{r}}}, \mathrm{G}=\frac{\tau_{\mathrm{a}}}{\gamma_{\mathrm{a}}}
$$

It is noted that the secant shear modulus is reduced to half the initial shear modulus when shear strain becomes equal to the reference strain [66]. According to this, the reference shear strain amplitude $\left(\gamma_{\mathrm{r}}\right)$ is accepted as the shear strain amplitude at which the initial shear modulus of a sample falls to half the value. The trend lines shown in the graphs of the shear modulus and modulus reduction curves (Figures 7 and 8) were calculated depending on the reference shear strain amplitude with the hyperbolic model described by Ishihara [66].

Damping ratio (D) of soils reflects the energy dissipation properties subjected to the cyclic or dynamic load. When the results presented in Table 7 are evaluated in terms of the damping ratio in general, it can be seen that $\mathrm{D}$ decreases with the increase of the effective cell pressure. Since the internal structure of the SF-mixed soil samples became denser with the increase of the effective cell pressure and the bond between the soil particles became stronger, vibration waves could be propagated more evenly from the top to the bottom of the sample. Similar results were seen in the results of the resonant column test performed by Lang et al. [67] on silty clay soils stabilized with fly ash and cement. When the damping 
ratio graphs were assessed, it was seen that similar results $(\mathrm{D}=3-5 \%)$ were obtained for all samples at low shear strain amplitude $(\gamma=0.001 \%)$ and at all effective cell pressure values $\left(\sigma_{0}^{\prime}=20,40\right.$ and $\left.60 \mathrm{kPa}\right)$ (Table 7 and Figure 8)

The resonant column apparatus used in the study is capable of measuring at high shear strain amplitude $(\gamma=0.1 \%)$, which is used to simulate earthquake loadings. Therefore, the shear modulus and the damping ratio values of all the samples at high shear strain amplitude $(\gamma=0.1 \%$ ) were calculated in the experimental study (Table 7 and Figure 8).

Twenty percent SF-mixed samples had the lowest initial shear modulus values depending on the test results (Table 7 and Figure 7e). The initial shear modulus values started to increase depending on increasing the amount of mixture $(25 \%, 30 \%)$. In this case, the change in initial shear modulus values were interpreted as increased effectiveness of silica fume on the mixed sample, as seen in Table 7.

Table 7. The effect of samples mixed with different ratios of silica fume on resonant column test results.

\begin{tabular}{|c|c|c|c|c|c|c|c|c|}
\hline SF (\%) & $\boldsymbol{\sigma}_{0}^{\prime}(\mathbf{k P a})$ & $\mathrm{G}_{0}(\mathrm{MPa})$ & $\mathrm{G}_{0 / 2}(\mathrm{MPa})$ & $\gamma_{\mathrm{r}}(\%)$ & $\begin{array}{c}\mathrm{G}_{\gamma=0.1 \%} \\
(\mathrm{MPa})\end{array}$ & $\mathrm{G}_{\gamma=\% 0.1} / \mathrm{G}_{0}$ & $\begin{array}{c}D_{\gamma=\% 0.001} \\
(\%)\end{array}$ & $\begin{array}{c}D_{\gamma=\% 0.1} \\
(\%)\end{array}$ \\
\hline \multirow{3}{*}{0} & 20 & 80.60 & 40.300 & 0.0563 & 26.67 & 0.330 & 6.0 & 16.0 \\
\hline & 40 & 84.93 & 42.470 & 0.0667 & 35.50 & 0.420 & 5.0 & 16.0 \\
\hline & 60 & 86.40 & 43.200 & 0.0785 & 39.39 & 0.460 & 4.0 & 17.0 \\
\hline \multirow{3}{*}{5} & 20 & 74.42 & 37.210 & 0.0286 & 17.59 & 0.240 & 4.5 & 22.5 \\
\hline & 40 & 84.28 & 42.140 & 0.0450 & 26.46 & 0.310 & 4.0 & 20.5 \\
\hline & 60 & 88.70 & 44.350 & 0.0500 & 29.82 & 0.340 & 4.0 & 18.5 \\
\hline \multirow{3}{*}{10} & 20 & 75.00 & 37.500 & 0.0439 & 21.97 & 0.290 & 4.0 & 17.5 \\
\hline & 40 & 80.00 & 40.000 & 0.0608 & 29.19 & 0.360 & 4.0 & 17.5 \\
\hline & 60 & 86.41 & 43.210 & 0.0582 & 33.64 & 0.390 & 3.0 & 15.3 \\
\hline \multirow{3}{*}{15} & 20 & 81.39 & 40.700 & 0.0356 & 18.95 & 0.230 & 5.0 & 17.5 \\
\hline & 40 & 96.30 & 48.150 & 0.0516 & 32.47 & 0.340 & 4.5 & 15.0 \\
\hline & 60 & 99.43 & 49.720 & 0.0549 & 38.10 & 0.380 & 3.5 & 15.0 \\
\hline \multirow{3}{*}{20} & 20 & 68.53 & 34.270 & 0.0501 & 20.59 & 0.300 & 5.0 & 18.2 \\
\hline & 40 & 75.28 & 37.640 & 0.0672 & 29.30 & 0.390 & 4.5 & 15.7 \\
\hline & 60 & 78.07 & 39.040 & 0.0715 & 30.17 & 0.390 & 4.0 & 12.5 \\
\hline \multirow{3}{*}{25} & 20 & 76.37 & 38.185 & 0.0594 & 25.05 & 0.328 & 3.5 & 22.2 \\
\hline & 40 & 79.17 & 39.585 & 0.0715 & 32.72 & 0.413 & 4.0 & 15.7 \\
\hline & 60 & 80.59 & 40.295 & 0.0732 & 33.63 & 0.417 & 4.0 & 14.4 \\
\hline \multirow{3}{*}{30} & 20 & 84.93 & 42.470 & 0.0440 & 19.79 & 0.233 & 4.8 & 20.0 \\
\hline & 40 & 90.89 & 45.450 & 0.0640 & 32.72 & 0.360 & 4.8 & 20.0 \\
\hline & 60 & 92.41 & 46.205 & 0.0715 & 40.40 & 0.437 & 4.8 & 14.5 \\
\hline
\end{tabular}

$\overline{\mathrm{SF}}=$ silica fume ratio; $\sigma_{0}^{\prime}=$ effective cell pressure; $\mathrm{G}_{0}=$ initial shear modulus; $\mathrm{G}_{0 / 2}=$ shear modulus at reference shear strain amplitude; $\gamma_{\mathrm{r}}=$ reference shear strain amplitude; $\mathrm{G}_{\gamma=0.1 \%}=$ shear modulus at $0.1 \%$ shear strain amplitude; $\mathrm{G}_{\gamma=\% 0.1} / \mathrm{G}_{0}=$ modulus reduction ratio value at $0.1 \%$ shear strain amplitude; $\mathrm{D}_{\gamma=\% 0.001}=$ damping ratio value at $0.001 \%$ shear strain amplitude; $\mathrm{D}_{\gamma=\% 0.1}=$ damping ratio value at $0.1 \%$ shear strain amplitude.

It was observed that increasing the silica fume did not always increase the shear modulus. The silica fume-clay ratio should be sufficient to provide pozzolanic activity. Fifteen percent SF-mixed samples had the highest initial shear modulus values according to the resonant column test results since the silica fume-clay ratio was at the ideal level to ensure pozzolanic activity. 

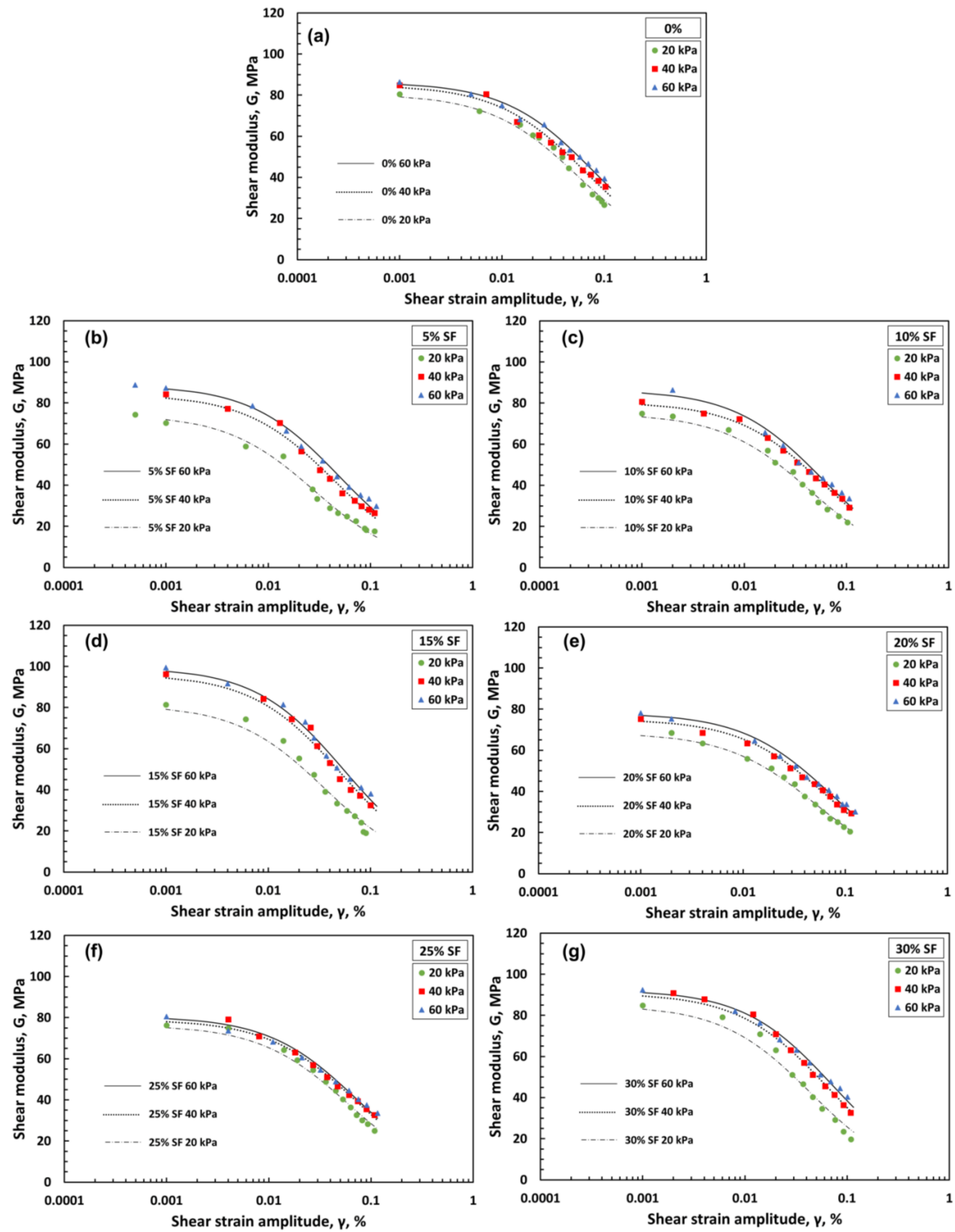

Figure 7. Shear modulus dependence on shear strain amplitude for all samples. (a) $0 \% \mathrm{SF}$, (b) $5 \% \mathrm{SF}$, (c) $10 \% \mathrm{SF}$, (d) $15 \% \mathrm{SF}$, (e) $20 \% \mathrm{SF}$, (f) $25 \% \mathrm{SF},(\mathrm{g}) 30 \% \mathrm{SF}$.

As mentioned, the study focused on shallow soil stabilization. Therefore, applied effective cell pressure values on the samples are low $(20,40$ and $60 \mathrm{kPa})$. It was seen in the studies that the effect of effective cell pressure on the damping ratio occurs at high values, especially in clay soils [66]. According to this, the damping ratio curves for all samples were relatively similar since effective cell pressure on the samples was low in the study. Therefore, it may be necessary to perform studies at different effective cell pressures for deep improvements. 

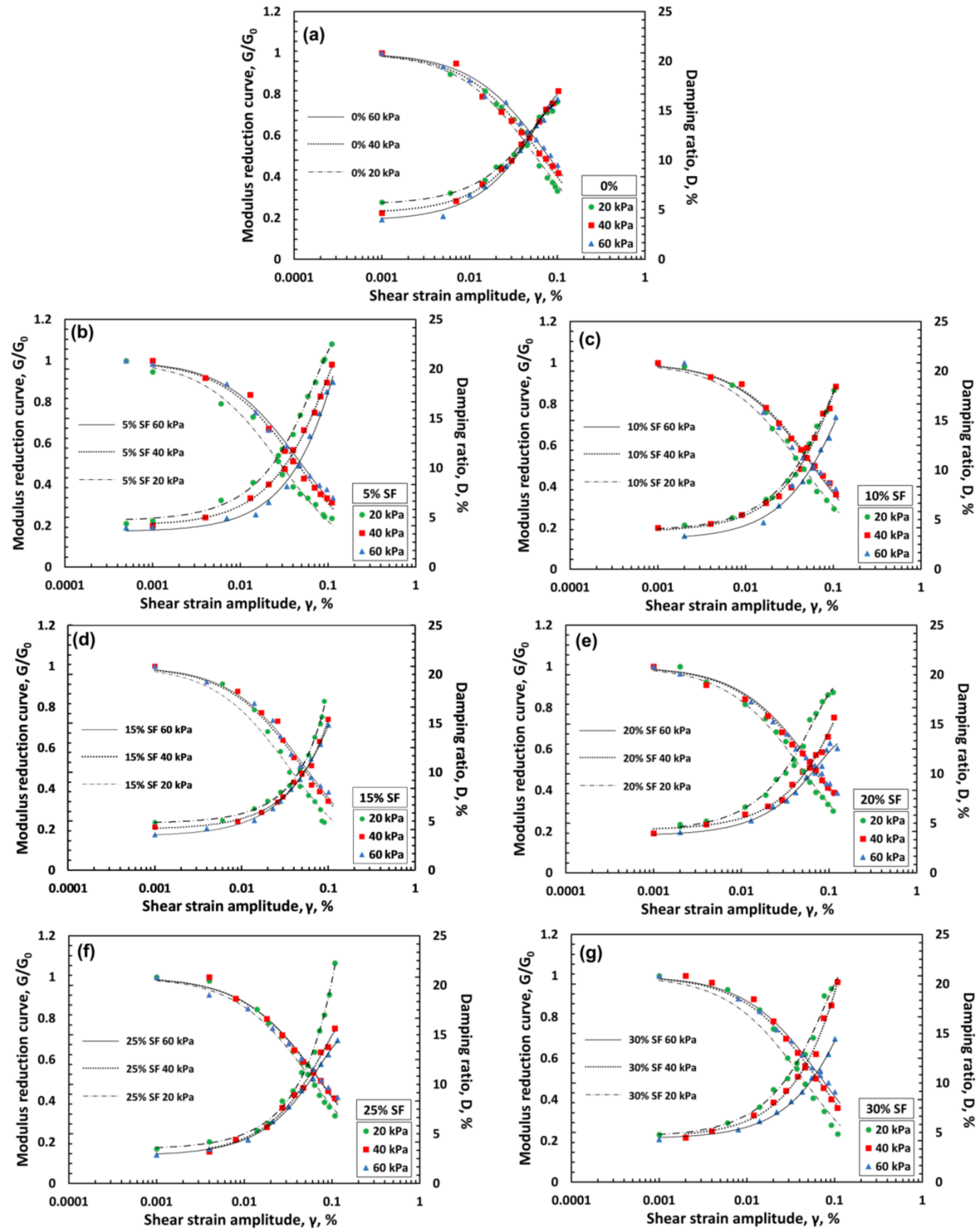

Figure 8. Damping ratio and modulus reduction curves dependence on shear strain amplitude for all samples. (a) $0 \% \mathrm{SF}$, (b) $5 \% \mathrm{SF}$, (c) $10 \% \mathrm{SF}$, (d) $15 \% \mathrm{SF}$, (e) $20 \% \mathrm{SF}$, (f) $25 \% \mathrm{SF}$, (g) $30 \% \mathrm{SF}$.

In Figure 9, the relations of the initial shear modulus of the samples created from 0 , $5,10,15,20,25$ and 30\% SF content according to the effective cell pressure (at 20, 40 and $60 \mathrm{kPa})$ at low shear strain amplitude $(\gamma=0.001 \%)$ are given. From the results, the initial shear modulus values of the sample mixed with 15\% SF were highest at 40 and $60 \mathrm{kPa}$ compared to other samples (Figures 7 and 9, Table 7), although the initial shear modulus value of the $15 \%$ SF sample, even under the $30 \%$ SF sample, was relatively higher than the $0 \%$ SF sample at $20 \mathrm{kPA}$. 


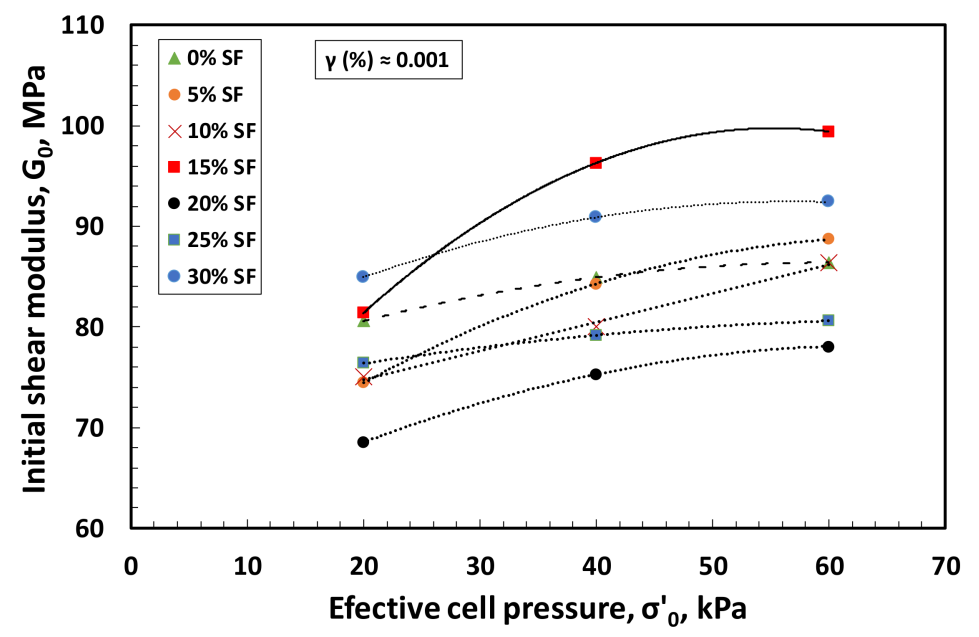

Figure 9. Comparison of initial shear modulus values of mixed samples mixed according to the effective cell pressure at low shear strain amplitude $(\gamma=0.001 \%$.).

From the resonant column tests, the initial shear modulus values of the mixed sample containing 15\% silica fume at effective cell pressure 20, 40 and $60 \mathrm{kPa}$ were found to be higher: 1,14 and 15\% (Figure 9) with respect to initial shear modulus values of nonmixed sample at low shear strain amplitude $(\gamma=0.001 \%)$. In addition, $15 \%$ silica fume samples were calculated to have the highest initial shear modulus values, 40 and $60 \mathrm{kPa}$ effective pressures, of the all samples. After one-day curing, it is seen that $5 \%$ and $10 \%$ SF mixed samples had low initial shear modulus since the silica fume-soil ratio that would interact with pozzolanic was not at a sufficient level. In addition, since discontinuity occurs in the samples with 20 and $25 \% \mathrm{SF}$, due to unreacted silica fume, these samples had the lowest value of initial shear modulus due to the voids and discontinuity.

The initial shear modulus values of 30\% SF mixed sample gave the second best values at low shear strain amplitude. The increase in initial shear modulus values was considered as increased effectiveness of silica fume on the mixed sample. It is thought to be caused by the increase in the amount of silica fume and void filling in the sample. At $20 \mathrm{kPa}$ effective pressure, the difference between the initial shear modulus of $15 \%$ SF and 30\% SF samples was approximately $4 \%$ and at a negligible level. Otherwise, the $20 \mathrm{kPa}$ cell pressure was evaluated low to determine the increasing effect of cell pressure on the samples.

\section{Conclusions}

In this paper, the performance of the silica fume additive used for shallow stabilization in terms of engineering applications in dispersive soils was studied by conducting Atterberg limits, standard Proctor compaction, pinhole and resonant column tests. The findings are summarized as follows.

- Silica fume reduced both the plastic index (PI) and liquid limit (LL) of dispersive soil. Due to this alteration in the property of dispersive soil, the soil changed its USCS classification, from high plasticity clay $(\mathrm{CH})$ to low plasticity silt (ML). Due to the transformation of the $\mathrm{CH}$ to $\mathrm{ML}$, the plasticity of the reinforced sample was reduced, and hence the reinforced dispersive soil showed a stable nature.

- The maximum dry density value, which was $1.584 \mathrm{Mg} / \mathrm{m}^{3}$ without additives, was reduced to $1.559 \mathrm{Mg} / \mathrm{m}^{3}$ at $15 \%$ additive content. There were no significant changes in maximum dry density values with increasing SF contents. The increase in optimum water content was relatively limited.

- Based on the pinhole test result, the addition of $25 \%$ silica fume with one day curing time changed the soil from D1 to ND2 classification. The improvement at 25\% SF content was due to the high amount of silica fume required to balance the high amount of sodium cations in the soil sample. 
- From the resonant column tests, the initial shear modulus values of the mixed sample containing $15 \%$ silica fume at effective cell pressure 20,40 and $60 \mathrm{kPa}$ were found to be higher, 1,14 and $15 \%$, with respect to the initial shear modulus values of nonmixed sample.

- For all the samples, relatively similar trends were obtained in terms of the damping ratio and modulus reduction values under wide shear strain amplitude. In addition, the relatively highest damping ratio values at $\gamma=0.1 \%$ was obtained from $5 \% \mathrm{SF}$ samples for all effective cell pressures.

- The initial shear modulus values of the $30 \%$ SF mixed sample gave the second best values at low shear strain amplitude. The increase in initial shear modulus values were considered as increased effectiveness of silica fume on mixed sample.

- When the modulus reduction curves are examined, it is seen that all the samples lost more than half of their initial shear modulus values at high shear strain amplitude $(\gamma=0.1 \%)$. The highest modulus reduction values, which were $0.330,0.420$ and 0.460 , were obtained from the nonmixed sample at high shear strain amplitude for all effective cell pressures.

- At $20 \mathrm{kPa}$, the samples containing 15 and 30\% SF with the highest initial shear modulus at low shear strain had the lowest modulus reduction values, 0.230 and 0.233 , respectively, at high shear strain amplitude $\gamma=0.1 \%$. The reason for this was that the initial shear modulus of the relevant samples at $\gamma=0.001 \%$ was higher than the other samples.

In future studies, examining the effect of the silica fume additive on the dynamic properties of dispersive soils at different curing times is considered important for the long-term performance of the silica fume.

Author Contributions: Conceptualization, formal analysis, methodology; writing, review and editing, M.T.; methodology, writing, review and editing, S.U.U.; investigation, experimental design and data interpretation, O.Ö. All authors have read and agreed to the published version of the manuscript.

Funding: This research was supported by the Scientific Research Project of Eskisehir Osmangazi University (Project No: 201915037).

Institutional Review Board Statement: Not applicable.

Informed Consent Statement: Not applicable.

Data Availability Statement: Not applicable.

Conflicts of Interest: The authors declare no conflict of interest.

\section{References}

1. Sherard, J.L.; Dunnigan, L.P.; Decker, R.S. Identification and nature of dispersive soils. J. Geotech. Eng. Div. 1976, 102, $287-301$. [CrossRef]

2. Indraratna, B.; Nutalaya, P.; Kuganenthira, N. Stabilization of a dispersive soil by blending with fly ash. Q. J. Eng. Geol. Hydrogeol. 1991, 24, 275-290. [CrossRef]

3. Richards, K.S.; Reddy, K.R. Critical appraisal of piping phenomena in earth dams. Bull. Eng. Geol. Environ. 2007, 66, $381-402$. [CrossRef]

4. Umesha, T.S.; Dinesh, S.V.; Sivapullaiah, P.V. Control of dispersivity of soil using lime and cement. Int. J. Geol. 2009, 3, 8-16.

5. Abbasi, N.; Nazifi, M.H. Assessment and modification of sherard chemical method for evaluation of dispersion potential of soils. Geotech. Geol. Eng. 2013, 31, 337-346. [CrossRef]

6. Premkumar, S.; Piratheepan, J.; Arulrajah, A.; Disfani, M.M.; Rajeev, P. Experimental study on contact erosion failure in pavement embankment with dispersive clay. J. Mater. Civ. Eng. 2016, 28, 04015179. [CrossRef]

7. Hassanlourad, M.; Rokni, M.N.; Hassanlo, M.; Badrlou, A. Dispersive clay stabilised by alum and lime. Int. J. GEOMATE 2017, 12, 156-162. [CrossRef]

8. Goodarzi, A.; Salimi, M. Stabilization treatment of a dispersive clayey soil using granulated blast furnace slag and basic oxy-gen furnace slag. Appl. Clay Sci. 2015, 108, 61-69. [CrossRef]

9. Abdelkader, B.; Abdeldjalil, Z.; Abdelmalek, B. Use of milk of lime for dispersive soil treatment in the region of Tlemcen in Algeria. Int. J. Emerg. Technol. Adv. Eng. 2012, 2, 281-286. 
10. Bhuvaneshwari, S.; Soundra, B.; Robinson, R.G.; Gandhi, S.R. Stabilization and microstructural modification of dispersive clayey soils. In Proceedings of the First Sri Lankan Geotechnical Society (SLGS) International Conference on Soil and Rock Engineering, Colombo, Sri Lanka, 6-11 August 2007.

11. Savaş, H.; Türköz, M.; Seyrek, E.; Ünver, E. Comparison of the effect of using class C and F fly ash on the stabilization of dispersive soils. Arab. J. Geosci. 2018, 11, 612. [CrossRef]

12. Turkoz, M.; Vural, P. The effects of cement and natural zeolite additives on problematic clay soils. Sci. Eng. Compos. Mater. 2013, 20, 395-405. [CrossRef]

13. Turkoz, M.; Savas, H.; Acaz, A.; Tosun, H. The effect of magnesium chloride solution on the engineering properties of clay soil with expansive and dispersive characteristics. Appl. Clay Sci. 2014, 101, 1-9. [CrossRef]

14. Joga, J.R.; Varaprasad, B.J.S. Effect of xanthan gum biopolymer on dispersive properties of soils. World J. Eng. 2020, 17, 563-571. [CrossRef]

15. Yoder, E.J.; Witczak, M.W. Principles of Pavement Design, 2nd ed.; John Wiley \& Sons, Inc.: Hoboken, NJ, USA, $1975 ;$ p. 699.

16. Papworth, H.F. Production of Silica Fume; Civil Engineering: Melbourne, Australia, 1997.

17. Köksal, F.; Altun, F.; Yiğit, I.; Şahin, Y. Combined effect of silica fume and steel fiber on the mechanical properties of high strength concretes. Constr. Build. Mater. 2008, 22, 1874-1880. [CrossRef]

18. Ortega, J.M.; Esteban, M.D.; Williams, M.; Sánchez, I.; Climent, M.Á. Short-term performance of sustainable silica fume mortars exposed to sulfate attack. Sustainability 2018, 10, 2517. [CrossRef]

19. Sadrmomtazi, A.; Tahmouresi, B.; Saradar, A. Effects of silica fume on mechanical strength and microstructure of basalt fiber reinforced cementitious composites (BFRCC). Constr. Build. Mater. 2018, 162, 321-333. [CrossRef]

20. Wang, X.-Y. Effect of carbon pricing on optimal mix design of sustainable high-strength concrete. Sustainability $2019,11,5827$. [CrossRef]

21. Silva, L.R.R.D.; Silva, J.A.D.; Francisco, M.B.; Ribeiro, V.A.; de Souza, M.H.B.; Capellato, P.; Souza, M.A.; Claret dos Santos, V.; Cesar Gonçalves, P.; de Lourdes Noronha Motta Melo, M. Polymeric waste from recycling refrigerators as an aggregate for self-compacting concrete. Sustainability 2020, 12, 8731. [CrossRef]

22. Kalkan, E.; Akbulut, S. The positive effects of silica fume on the permeability, swelling pressure and compressive strength of natural clay liners. Eng. Geol. 2004, 73, 145-156. [CrossRef]

23. Goodarzi, R.; Akbari, H.R.; Salimi, M. Enhanced stabilization of highly expansive clays by mixing cement and silica fume. Appl. Clay Sci. 2016, 132-133, 675-684. [CrossRef]

24. Türköz, M.; Savaş, H.; Tasci, G. The effect of silica fume and lime on geotechnical properties of a clay soil showing both swelling and dispersive features. Arab. J. Geosci. 2018, 11, 735. [CrossRef]

25. Holland, T.C.; Detwiler, R. Guide for the Use of Silica Fume in Concrete; ACI Committee Report: Farmington Hills, MI, USA, 2006; p. 63.

26. Al-Mansour, A.; Chow, C.L.; Feo, L.; Penna, R.; Lau, D. Green concrete: By-products utilization and advanced approaches. Sustainability 2019, 11, 5145. [CrossRef]

27. Tafheem, Z.; Khusru, S.; Nasrin, S. Environmental Impact of Green Concrete in Practice ICMERE2011-PI-069. In Proceedings of the 1st International Conference on Mechanical Engineering and Renewable Energy (ICMERE), Chittagong, Bangladesh, 22-24 December 2011.

28. Ay, N.; Topçu, İ.B. The influence of silico ferrochromium fumes on concrete properties. Cem. Concr. Res. 1995, 25, 387-394. [CrossRef]

29. Tonak, T.; Sipahi, F.; Atay, Y. The use of silica fume, a waste product of the electrometallurgy industry, in Cement Production. In Symposium on the Use of Industrial Wastes in the Construction Sector; Proceedings Book; TMMOB Chamber of Civil Engineers: Ankara, Turkey, 1997; pp. 169-183.

30. Topçu, İ.B.; Kaval, M. Economical analysis of use of silica fume in concrete. J. Eng. Archit. Fac. Osman. Univ. 2001, 14, 18-31.

31. Asavapisit, S.; Nanthamontry, W.; Polprasert, C. Influence of condensed silica fume on the properties of cement-based solidified wastes. Cem. Concr. Res. 2001, 31, 1147-1152. [CrossRef]

32. Mastali, M.; Abdollahnejad, Z. Carbon dioxide sequestration on fly ash/waste glassalkali-based mortars with recycled aggregates: Compressive strength, hydration products, carbon footprint, and cost analysis. Carbon Dioxide Sequestration Cem. Constr. Mater. 2018, 299-348. [CrossRef]

33. Schneider, M.; Romer, M.; Tschudin, M.; Bolio, H. Sustainable cement production—Present and future. Cem. Concr. Res. 2011, 41, 642-650. [CrossRef]

34. Liu, H.; Luo, G.; Wang, L.; Wang, W.; Li, W.; Gong, Y. Laboratory evaluation of eco-friendly pervious concrete pavement material containing silica fume. Appl. Sci. 2019, 9, 73. [CrossRef]

35. Živica, V. Sulfate resistance of the cement materials based on the modified silica fume. Constr. Build. Mater. 2000, 14, 17-23. [CrossRef]

36. Wu, W.J.; Wang, R.; Zhu, C.Q.; Meng, Q.S. The effect of fly ash and silica fume on mechanical properties and durability of coral aggregate concrete. Constr. Build. Mater. 2018, 185, 69-78. [CrossRef]

37. Sezer, G.İ. Compressive strength and sulfate resistance of limestone and/or silica fume mortars. Constr. Build. Mater. 2012, 26, 613-618. [CrossRef] 
38. Abd El-Aziz, M.A.; Abo-Hashema, M.A.; El-Shourbagy, M. The effect of lime-silica fume stabilizer on engineering properties of clayey subgrade. In Proceedings of the Fourth Mansoura International Engineering Conference (4th IEC), Faculty of Engineering, Mansoura, Egypt, 20-22 April 2004. Paper No. 96.

39. Al-Zairjawi, M.K. Effect of adding cement and silica fume with cement on compaction properties and shear strength of clayey soil. Al-Qadisiyah J. Eng. Sci. 2009, 2, 253-261.

40. Bharadwaj, S.; Trivedi, M.K. Impact of micro silica fume on engineering properties of expansive soil. Int. J. Sci. Technol. Eng. 2016, $2,435-440$.

41. Amina, S.M.; Rani, V. Control of dispersivity of soil using lime and silica fume. Int. J. Res. Appl. Sci. Eng. Technol. 2017, 5, 386-391.

42. Al-Soudany, K.Y. Improvement of expansive soil by using silica fume. Kufa J. Eng. 2017, 9, 222-239. [CrossRef]

43. Fattah, M.Y.; Al-Saidi, A.A.; Jaber, M.M. Improvement of bearing capacity of footing on soft clay grouted with lime-silica fume mix. Géoméch. Eng. 2015, 8, 113-132. [CrossRef]

44. Kalkan, E. Influence of silica fume on the desiccation cracks of compacted clayey soils. Appl. Clay Sci. 2009, 43, 296-302. [CrossRef]

45. Kalkan, E. Impact of wetting-drying cycles on swelling behavior of clayey soils modified by silica fume. Appl. Clay Sci. 2011, 52, 345-352. [CrossRef]

46. Tiwari, N.; Satyam, N. Experimental study on the influence of polypropylene fiber on the swelling pressure expansion attributes of silica fume stabilized clayey soil. Geosciences 2019, 9, 377. [CrossRef]

47. American Society for Testing and Materials (ASTM). Standard Test Method for Particle Size Analysis of Soils; ASTM International: West Conshohocken, PA, USA, 2007.

48. American Society for Testing and Materials (ASTM). Standard Test Methods for Liquid Limit, Plastic Limit, and Plasticity Index of Soils; ASTM International: West Conshohocken, PA, USA, 2005.

49. American Society for Testing and Materials (ASTM). Standard Practice for Classification of Soils for Engineering Purposes (Unified Soil Classification System); ASTM International: West Conshohocken, PA, USA, 2011.

50. American Society for Testing and Materials (ASTM). Standard Test Method for Specific Gravity of Soil Solids by Water Pycnometer; ASTM International: West Conshohocken, PA, USA, 2002.

51. American Society for Testing and Materials (ASTM). Standard Test Methods for Laboratory Compaction Characteristics of Soil Using Standard Effort; ASTM International: West Conshohocken, PA, USA, 2000.

52. Bell, F.G.; Walker, D.J.H. A further examination of the nature of dispersive soils in Natal, South Africa. Q. J. Eng. Geol. Hydrogeol. 2000, 33, 187-199. [CrossRef]

53. Zhang, Z.; Zhang, B.; Yan, P. Comparative study of effect of raw and densified silica fume in the paste, mortar and concrete Constr. Build. Mater. 2016, 105, 82-93. [CrossRef]

54. U.S. Department of the Interior Bureau of Reclamation (USBR-5410). Determining Dispersibility of Clayey Soils by the Pinhole Test Method; Earth Manual II: Denver, CO, USA, 1989.

55. Youn, J.; Choo, Y.; Kim, D. Measurement of small-strain shear modulus Gmax of dry and saturated sands by bender element, resonant column, and torsional shear tests. Can. Geotech. J. 2008, 45, 1426-1438. [CrossRef]

56. Likitlersuang, S.; Teachavorasinskun, S.; Surarak, C.; Oh, E.; Balasubramaniam, A. Small strain stiffness and stiffness degradation curve of Bangkok Clays. Soils Found. 2013, 53, 498-509. [CrossRef]

57. American Society for Testing and Materials (ASTM). Standard Test Methods for Modulus and Damping of Soils by the Resonant-Column Method; ASTM International: West Conshohocken, PA, USA, 2000.

58. Okur, D.V.; Umu, S.U. Dynamic properties of clean sand modified with granulated rubber. Adv. Civ. Eng. 2018, $2018,1-11$. [CrossRef]

59. Phanikumar, B.R.; Jagapathi, R.M.; Ramanjaneya, R.E. Silica fume stabilization of an expansive clay subgrade and the effect of silica fume-stabilised soil cushion on its CBR. Géoméch. Geoengin. 2020, 15, 64-77. [CrossRef]

60. Al-Azzawi, A.A.; Daud, K.A.; Sattar, M.A.A. Effect of silica fume addition on the behavior of silty-clayey soils. J. Eng. Dev. 2012, 16, 92-105.

61. Elges, H.F.W.K. Dispersive Soils: Problem Soils in South Africa-State of the Art; Civil Engineer: Pretoria, South Africa, 1985; Volume 27, pp. 347-349.

62. Knodel, P.C. Characteristics and Problems of Dispersive Clay Soils; R91-09; United States Department of the Interior Bureau of Reclamation, Materials Engineering Branch: Denver, CO, USA, 1991.

63. Penner, D.; Lagaly, G. Influence of anions on the rheological properties of clay mineral dispersions. Appl. Clay Sci. 2001, 19, 131-142. [CrossRef]

64. Ouhadi, V.R.; Yong, R.N.; Amiri, M.; Ouhadi, M.H. Pozzolanic consolidation of stabilized soft clays. Appl. Clay Sci. 2014, 95, 111-118. [CrossRef]

65. Vakili, A.H.; Selamat, M.R.; Moayedi, H. Effects of using pozzolan and Portland cement in the treatment of dispersive clay. Sci. World J. 2013, 2013, 1-10. [CrossRef]

66. Ishihara, K. Soil Behavior in Earthquake Geotechnics; Clarendon-Oxford University Press: Oxford, UK, 1996 ; p. 385.

67. Lang, L.; Li, F.; Chen, B. Small-strain dynamic properties of silty clay stabilized by cement and fly ash. Constr. Build. Mater. 2020, 237, 117646. [CrossRef] 